\title{
The rural/urban wage gap in the industrialisation of Russia, I884-1910
}

\author{
LEONID BORODKIN, $\dagger$ BRIGITTE GRANVILLE $\ddagger$ \\ AND CAROL SCOTT LEONARD †† \\ $\dagger$ Moscow Lomonossov State University, Russia \\ $\ddagger$ Queen Mary, University of London \\ $\dagger \dagger$ †t Antony’s College, Oxford, carol.leonard@sant.ox.ac.uk
}

This article presents econometric evidence of integration in rural and urban wages in Russia's Northwest in the late tsarist era. Using the Autoregressive Distributed Lag (ARDL) approach to co-integration and error correction modelling, we show the flexibility of the rural wage in response to the lagged rural/urban wage ratio. Applying the model developed by Boyer and Hatton (1994) and Hatton and Williamson (I99Ia, I99Ib, I992), we show the similarity of the wage gap in northwest Russia in the late tsarist era to that during industrialisation in the US, England and Western Europe. Although our evidence does not necessarily describe countrywide trends, it does support for an industrialising region the more positive view of the degree and nature of late tsarist economic growth. Growth was not slowing down, and there is little evidence of constraints on migration by traditional agrarian institutions.

\section{Introduction}

Industrialisation is associated with a fall in rural/urban wage differentials, signifying closer integration of labour markets as the traditional sector's productivity rises and the work force leaves the land. Not always dramatic, the fall in differentials can sometimes be obscured. Cost-of-living differences in urban and rural areas make up a significant part of the differential, and these are difficult to measure (Hatton and Williamson 1992). The differential also includes costs of transportation and the effect of demand-side shocks to urban manufacturing employment. Even in nominal terms, however, over the long run, a fall in nominal wage differentials in the industrialisation era should be detectable as the process becomes self-sustaining. The rural/urban wage gap may have fallen by just under a fifth during industrialisation in advanced western countries. It would not be expected that the gap would decline so sharply in Russia, since the process - and the time series - is cut off by war and revolution. We find, however, indications of long-run integration in the datagenerating process, implying a greater flexibility of rural markets than is often 
associated with this period. We argue that even for this limited case study, the behaviour of the wage gap during pre-revolutionary Russian industrialisation sheds light on self-sustaining growth in agriculture and industry.

This article contributes to a growing literature critical of the traditional depiction of the late tsarist Russian economy as backward, in need of major property rights reform and isolated from the rapidly modernising world economy. The challenge to traditional narratives has been based on solid quantitative measures. A major western re-evaluation emerged in new national income estimates by Gregory (1982); a further reassessment showed Russia's wheat market by World War I to have been integrated into global trade (Goodwin and Grennes I998). As discussed below, however, area specialists continue to emphasise a more pessimistic view of the overwhelmingly agrarian economy of I9I4. Russia's persistent poverty and backwardness is embedded in explanations for the revolution of 1917.

Our article approaches the issue from a regional perspective based on new labour market data for St Petersburg guberniia (province), the region surrounding and including one of the capitals of the country. Our assessment shows empirically what Gregory (1994) argued to have been the case, that laws constraining rural out-migration were not an effective constraint. In any case, a point not appreciated in the classic view of Russia that labour was immobilised on the land, we underscore that only the repartitional communes, largely located in the South, tended to control members' departures from the village. The non-repartitional communes of the North and East did not have the incentive to do so in the r88os.

This article concerns the period from I884 to I9IO (the last year for which comparable rural and urban data are available) for the city of St Petersburg and the neighbouring villages, which were its main supply of labour for the pre-revolutionary era before World War I. We examine the data for evidence of regional bottlenecks in the labour market, including rural institutional barriers to migration. We design tests to explore the integration of rural and urban wages in this period of rapid industrial growth, which can reveal the presence and importance of obstacles to labour market mobility in this critical region.

The theory underlying our study explains the dynamic of the wage gap. It shows that the gap will widen in early industrialisation and then narrow as urban job creation generates greater diversity and opportunity. Increased out-migration from the village, permitted by the substitution of capital for labour in agriculture, increases the real rural/urban wage ratio, in principle growing toward parity as modern growth becomes self-sustaining. Migration does not entirely resolve spatial differentials during or after industrialisation. In advanced countries, as late as the I950s, rural wages were still some 30 per cent below urban wages. ${ }^{I}$ In the US, spatial segmentation between North

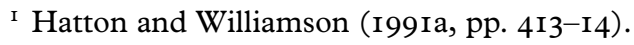


and South remained important - probably due to lagging productivity of agriculture in the South - after the Civil War (Margo 2002). The objective of estimation in our case is not so much to track the gap's downward trend as to detect long- and short-run properties. We use our case study for implications about the economic potential of the late tsarist economy.

The structure of this article is as follows. Section 2 examines conceptual issues on labour market integration and how they might shed light on issues in the writing of Russian economic history. Section 3 presents the data and methodology. We discuss problems in using nineteenth-century Russian industrial sources, since they are limited by time frame and quality. Section 4 describes the empirical results obtained using time series methodology to examine labour market integration. Section 5 describes the importance of the results of this case study for reassessing the development of labour markets during Russian industrialisation and their significance for the controversy over Russia's backwardness.

\section{Concepts and issues}

\section{I. Labour mobility and spatial integration}

A considerable historical literature on England and the US and studies of developing countries have focused on the determinants of labour migration, assessing its impact on spatial labour market integration. ${ }^{2}$ The models are useful for determining trends in different areas of the world and periods of history. The historical data for Russia are far more fragile and less abundant than for western countries, but well-tested assumptions for other countries and periods can make up for gaps and reveal the pace and extent of Russian labour market integration.

From the experience of the US and England, the mobility of labour, defined as the degree to which the propensity to move increases with larger incentives (such as movement in the wage gap), ${ }^{3}$ has a demonstrable empirical effect on labour market integration. ${ }^{4}$ Obstacles to labour mobility are assessed via the wage gap - labour market distortions that cannot be explained by cost-of-living adjustments. Over the long run, obstacles should diminish in spatially segmented markets and wages move towards equilibration, that is, toward a well-functioning labour market. The wage gap is therefore used to examine the degree of integration, although it is

\footnotetext{
${ }^{2}$ Boyer and Hatton (1997) review the evidence on the mobility of the labour force, migration and integration.

3 The slope of the migration function.

4 Williamson (1987, I990); Hatton and Williamson (I99Ib); Hunt (I986); Hunt and Pam (1997); Rothenberg (1988); Rosenbloom (1990, 1996); and some cautions that the relationship between labour mobility and migration is not straightforward in Boyer and Hatton (1997).
} 
not the only incentive determining migration between rural and urban areas; others are non-wage conditions, such as the extent of unemployment and the effect of relatives and friends in the destination city, and cost-of-living differences between town and city. It is important but frequently difficult to account quantitatively for these other conditions in understanding the process of industrialisation. 5

The basic growth model underlies the study of wage differentials. The main model, influenced by the writings of Theodore Schultz (I945) and developed by Sir W. Arthur Lewis (1954), was formalised and extended by John Fei and Gustav Ranis (I964), and made evolutionary by the same authors in I997. The latter provide a long time horizon in which capital accumulation and savings in the modern sector, at a constant wage, attract rural labour by job creation in cities while generating profits, which are then reinvested. Elastic supplies of 'surplus' (underemployed) rural labour and food, produced by the agricultural economy, are reallocated to the modern (service or export) sector in urban areas with surplus food providing subsistence for the population no longer involved in agricultural production.

Applications of the growth model to modern developing countries can frequently turn up distortions in labour markets difficult to resolve theoretically. It is generally thought that if rural labour were entirely flexible, there would be high mobility, with labour moving freely from lowerpaying to higher-paying positions and more productive uses. However, empirically, obstacles to rural/urban migration can slow or even stop the growth process. ${ }^{6}$ Labour absorption in urban areas can lag, even if rural wages remain low, and then population growth will outpace industrial expansion in the developing world. Developing countries will remain poor not because of inadequate supply of capital but, rather, the condition of underemployment in agriculture. This can occur where low-yielding labour-intensive production techniques persist, constraining rural demand for manufacturing products. Alternatively, imbalances in the labour market can be generated not by surplus in the agricultural sector but in the industrial sector, where rising profits are often reinvested in labour-saving technology. Rural in-migration may be slowed by urban job losses. Urban real wages can be institutionally driven and not responsive to labour supply, sticky downward, and rising over time, even where unemployment exists, due to labour market regulation (Todaro I969, I976).

Without measuring the actual rural/urban migration, research on the growth process can reveal trends by focusing on wage rigidity in the agricultural sector, which will weaken as transportation improves, passport regimes are removed, agriculture improves and employment opportunity

5 Boyer and Hatton (I997, p. 698).

${ }^{6}$ See Fei and Ranis (I997, p. I7) who provide an evolutionary model to explain obstacles in growth powerful enough to halt convergence. 
widens, increasing earnings dispersion during industrialisation. Again, some distortion will persist due to the influence of trade unions, government employment and minimum wage legislation (Rosenbloom I990).

\subsection{Labour mobility in late tsarist Russia}

Trends in the wage gap can help provide information about the nature of industrialisation in Russia before the revolution. Our study of the most rapidly industrialising region of St Petersburg provides a benchmark against which the spread of growth to other regions can be measured. Briefly, we address in this section the state of the controversy about the extent of rural backwardness in late tsarist history to which our study contributes.

Alexander Gerschenkron's study (1952) of tsarist Russian agrarian and industrial policies illustrated the concept of the 'advantage of backwardness', that is, the power of states to overcome major obstacles inhibiting industrialisation in backward rural countries by technological transfer. Russia at the start of industrialisation, he wrote, was burdened by limited demand. The lack of skills and manpower were only beginning to be overcome at the time of the Russian revolution of 1917. Restrictions on peasant movement, he argued, were effective. Although given personal freedom by the abolition of serfdom in I86I, peasants were tied to the repartitional land commune for a period of 49 years, while the commune on their behalf paid off redemption fees for the land they received as part of the settlement. The Emancipation provisions compensated the nobles, and the peasants repaid the mortgage loan to the state over 49 years, capitalised at 6 per cent annually. The system of krugovaia poruka, or mutual guarantees, especially within repartitional communes, solved agency problems in the state's requirement that peasants gain permission for travelling beyond 35 miles from their village.

Given constraints, Gerschenkron argued, the government could jumpstart industrialisation by large-scale investment in capital-intensive industries. This allowed economies of scale at large plants and the introduction of new technologies borrowed from more advanced countries. Gerschenkron gave economic support to an already ascendant political interpretation of the period, focusing on the policies of Sergei Witte (Finance Minister, I892-I903), which, after I897, used foreign savings to help build railroads and heavy industry. ${ }^{7}$ Foreign savings, along with the highly protectionist tariff, the decision to adopt the gold standard, low-interest state loans and privileged status given to export-oriented firms, were an industrial policy, in the dominant view, encouraging them to mobilise for exports energy, mineral and metallurgical resources. Gerschenkron wrote that by 1909, the private sector was sufficiently strengthened to sustain higher rates of growth.

\footnotetext{
7 See Gregory and Sailors (1976) for the importance of Gerschenkron's writing in a political frame; see also Barkai (I973), Goldsmith (I96I) and Kahan (1967).
} 
There was a 25 -fold increase in the production of coal from 1870 to I897, a 200-fold increase in oil. Rail lines more than doubled, and foreign investment flowed to new sectors of industry and new regions of the country. ${ }^{8}$ New rail networks linked the centre with Siberia and the East by transportation of capital goods as well as labour. A second boom from I 909 to I9I3 produced a far more diversified economy, Gerschenkron went on, including commercial sector banking, showing long-run effects of initial large investment in infrastructure. Thus, government intervention from a low base had the significant result of stimulating private-sector growth over the medium term.

Apart from the challenge to the notion of a systematic industrial policy under Witte, the main controversial element in this interpretation is the degree of rural backwardness in the I880s. According to Lenin's views the rural economy had enormous potential. Following him, a school of Soviet Russian Marxist historians built a substantial empirical base to show, by contrast with late nineteenth-century populist views of the countryside - later influencing Gerschenkron and others - evidence of 'rural capitalism' rapidly spreading (Kafengaus and Varzar 1929; Strumilin 1960; Nifontov 1974; Koval'chenko and Milov 1974; Bovykin et al. 1984, 1989). Koval'chenko showed large 'Prussian-style' estates in the Black Earth South of Russia and in the Baltic region owned by nobles becoming mechanised; small peasant farms in the South and on new lands in western Siberia, although less mechanised, showing entrepreneurship. ${ }^{9}$ Quantitative work on peasants' passports confirms significant rural immigration to cities between I86I and I900 (Rashin I940).

However, another school of Soviet historians, using non-quantitative approaches, was more sceptical. Also, using evidence from large estates, this school showed that the social structure of serfdom had scarcely dissipated in some regions. Even after its authority was abolished by the Stolypin reforms (I906-IO), the Russian land commune was of such obvious traditional importance that in the I 920 it spontaneously re-emerged as the fundamental organisation in the village. Only collectivisation, Danilov (1976) wrote, actually ended its authority. These historians concurred: capitalism was a shallow force up to I9I7 (Anfimov 1980; Anfimov, Danilova and Koroleva 1993; Danilov 1976). ${ }^{\text {IO }}$ Western writing, noted in the introduction, mostly also agreed, especially after Goldsmith's review of production data showed low rates of agricultural yield growth (I96I).

${ }^{8}$ Carstenson (1985, p. II4; 1984) argues that the importance of foreign investment, in general, has been overestimated in tsarist Russian industrialisation.

9 See Koval'chenko (I982).

Io See a review of Soviet and Russian writing on pre-revolutionary industrialisation by Borodkin (2006). 
Some economic historians were not so certain. Crisp (I976) wrote at length about the sustainability of agricultural growth in the nineteenth century. To criticism of 'shaky evidence' and 'premature' conclusions, ${ }^{\text {II }}$ Simms (I977) attempted to show that peasant consumption was rising, not falling. Gregory (I980, I982), Wheatcroft (I990) and Harrison (I990) wrote about faster-paced and more sweeping change, relying on fresh quantitative estimates. Gregory's national income estimates showed both urban and rural income improving beginning in the I880s. By crude proxies, Gregory found that urban personal consumption was rising at 4.2 and rural by 2.6 per cent per annum between I885 and 1900 (I980, pp. 56-7, I62, I27-9, I3I). ${ }^{\mathrm{I} 2}$ Leonard (I990) and Gregory (I980, I994) found that rural dwellers moved freely in some regions without regard for restrictions, in a trend that spread widely after laws that weakened them in 1897 and I903. ${ }^{13}$ Goodwin and Grennes (I998) reviewed trade data and provided new quantitative evidence in support of global integration.

Nevertheless, to some, the interpretation of more dramatic transformation of Russian agriculture in the late nineteenth century remains unsupported. Allen (2003) provided a fresh review of data to argue that Russian rural progress was not highly impressive at that time, by comparison with that of contemporary western countries; Allen's view is that agricultural productivity growth was so meagre that regardless of government intervention, the rate of advancement in pre-revolutionary times was not self-sustaining. ${ }^{\text {I4 }}$

In summary, no full consensus has yet been achieved explaining the emerging properties of the newly industrialising economy: was growth largely set in motion by state policy in the late nineteenth century, or, alternatively, had it begun earlier and already penetrated the rural sector with a force so powerful that agriculture kept up with manufacturing in a self-sustaining process once industrialisation began to accelerate?

\subsection{What can labour markets in and around St Petersburg show?}

The labour market in the Northwest is no doubt representative of that in the Baltic area and ahead of other regions in the country during industrialisation. Agriculture had long been improving in this area, because of the proximity of ports, even though soils were relatively infertile. Peasants specialised in production oriented toward the needs of large cities (livestock, crafts and vegetables), and they supplemented their earnings from agriculture by

II See Hamburg (I978, p. 48I).

I2 See also Mironov (2006, pp. 54I-6).

I3 See Leonard (1990) and (Gregory, I980).

${ }^{\text {I4 }}$ Allen (2003, p. 34): 'The nineteenth century sources of growth had run their course, and the most important had reversed direction. The prime mover behind the agricultural expansion had been the rise in the price of wheat.' 

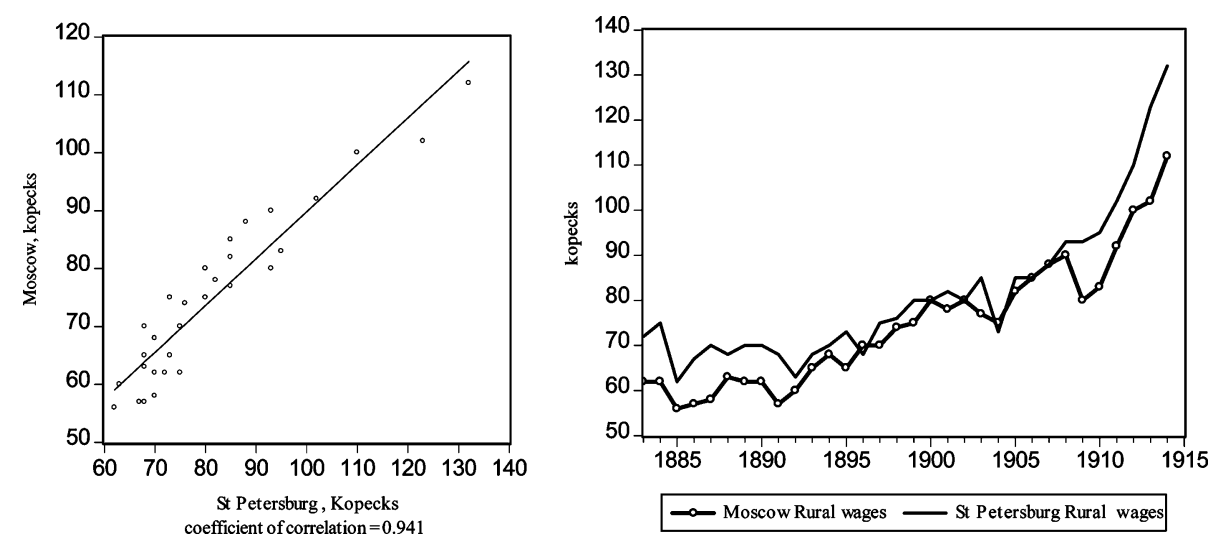

Figure I. Nominal daily rural wages, Moscow and St Petersburg gubernii, I884-I9IO

Source: See Appendix I.

outwork. To meet household consumption needs, they purchased imported grain for consumption from southern provinces.

Given that agricultural daily wages, as we show in Figure I, were correlated in Moscow and St Petersburg, markets across central Russia may not have been as segmented as is thought. Differences in industrial structure between the two cities, however, are noteworthy, and so we underscore the regional boundaries of our study (Figure 2).

The nominal annual factory wage in 1904 in St Petersburg was 366.2 roubles, well over the average for all of Russia of 213.9 roubles. ${ }^{15}$ In metal work in 1904, at the Putilov iron works (one of the largest in Russia) the average was 530 roubles, and at the Nevsky factory, 452 roubles. ${ }^{16}$ Prior to the I880s, labour was more expensive in St Petersburg due to costs of importing labour; St Petersburg manufacturers substituted capital for labour, fostering manufacturing differences between the two cities. ${ }^{17}$ Both cities were among the fastest growing in the world, with Moscow growing at 4 per cent annually between 1900 and I9I4 - at a rate equal to that of New York city. ${ }^{18} \mathrm{St}$ Petersburg was growing equally fast (Table I).

St Petersburg differed from other cities in that the working day was shorter and factories did not have to close for seasonal labour during the harvest. Beginning in the mid I880s, there was some effort to make factories elsewhere more competitive. The newly created Factory Inspectorate monitored the enforcement of a new series of labour laws. In I882, the employment of juveniles in night work and on Sundays and holidays was

I5 Svod ochet(1905, pp. I7I-5).

I6 Kiryanov and Volin (I989, p. II4).

${ }_{17}$ Tugan-Baranovsky (I922, pp. 312-29).

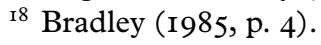




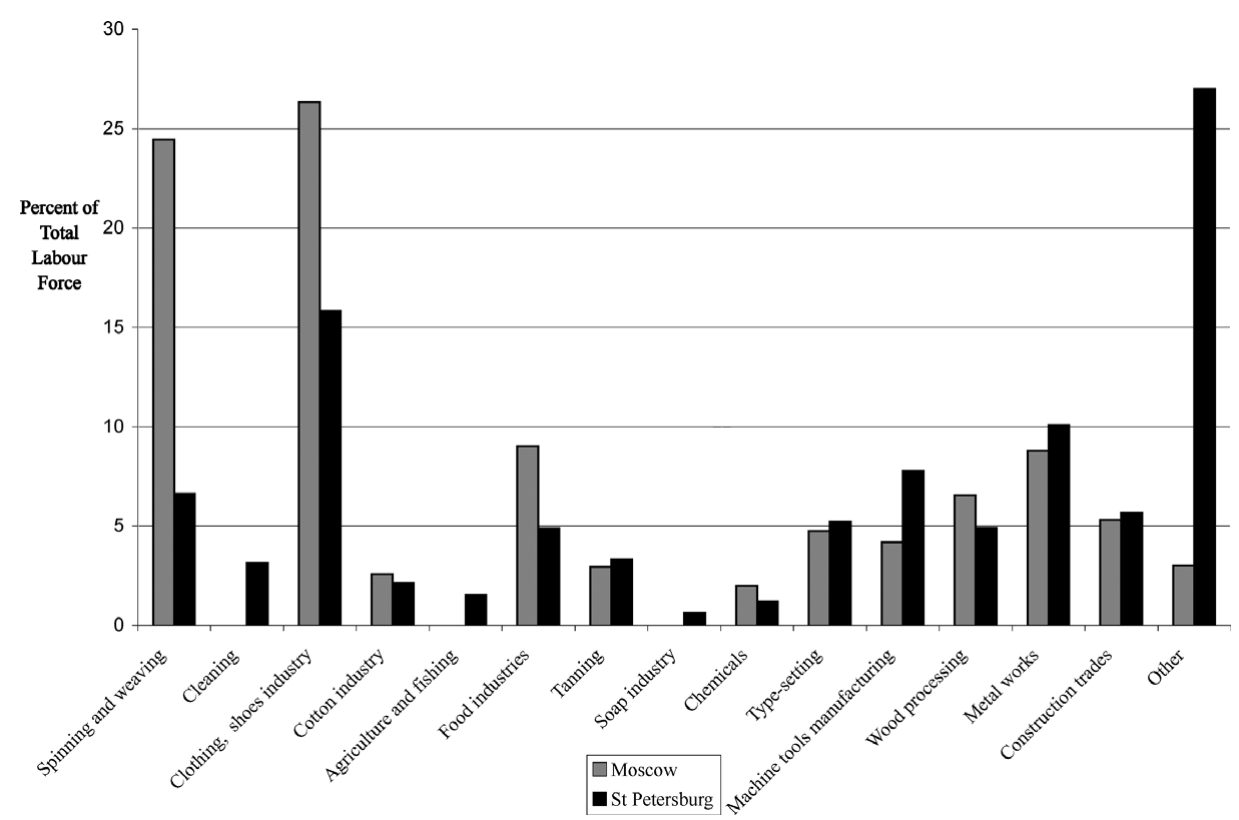

Figure 2. St Petersburg and Moscow, production structures compared, 1900

Source: Rashin (I956, p. 329).

Table I. Population growth in Moscow and St Petersburg in the nineteenth century*

\begin{tabular}{|c|c|c|c|c|c|c|c|c|}
\hline & \multicolumn{4}{|c|}{ Thousands of persons } & \multicolumn{4}{|c|}{ Percentage change } \\
\hline & I8I I & I863 & I897 & $\begin{array}{l}\text { I9I4 } \\
\text { (I.I I9I4) }\end{array}$ & $\begin{array}{l}\text { I8II- } \\
\text { I863 }\end{array}$ & $\begin{array}{l}\text { I864- } \\
\text { I897 }\end{array}$ & $\begin{array}{l}\text { I } 897^{-} \\
\text {I9I } 4\end{array}$ & $\begin{array}{l}\text { I8II-I9I4 } \\
\text { (I.I I9I4) }\end{array}$ \\
\hline Moscow & 270.2 & 462.5 & 1038.6 & I762.7 & I.7 & 2.2 & I.7 & 6.3 \\
\hline St Petersburg & 335.6 & 539.5 & I 264.9 & 2118.5 & I.6 & 2.3 & I. 7 & 6.3 \\
\hline
\end{tabular}

Source: Rashin (1956, p. 93).

ended; and in 1885, the law was extended to women's work in factories and juvenile and female labour in cotton, linen and woollen mills. In I897 the workday was limited to II.5 hours, down from roughly I5 hours, within a range of I2 to I8. Night work was permitted only up to Io hours. The two cities resembled each other more, with productivity increasing in Moscow, as ancillary expenses of the longer day fell and output per unit of input increased. To summarise, St Petersburg wage conditions were not unique, especially after the mid I880s.

For St Petersburg, the early i89os were decisive years. The left schedule of Figure 3 shows rising skill differentials for the building trades for $\mathrm{St}$ Petersburg, while the right schedule emphasises the differential between 

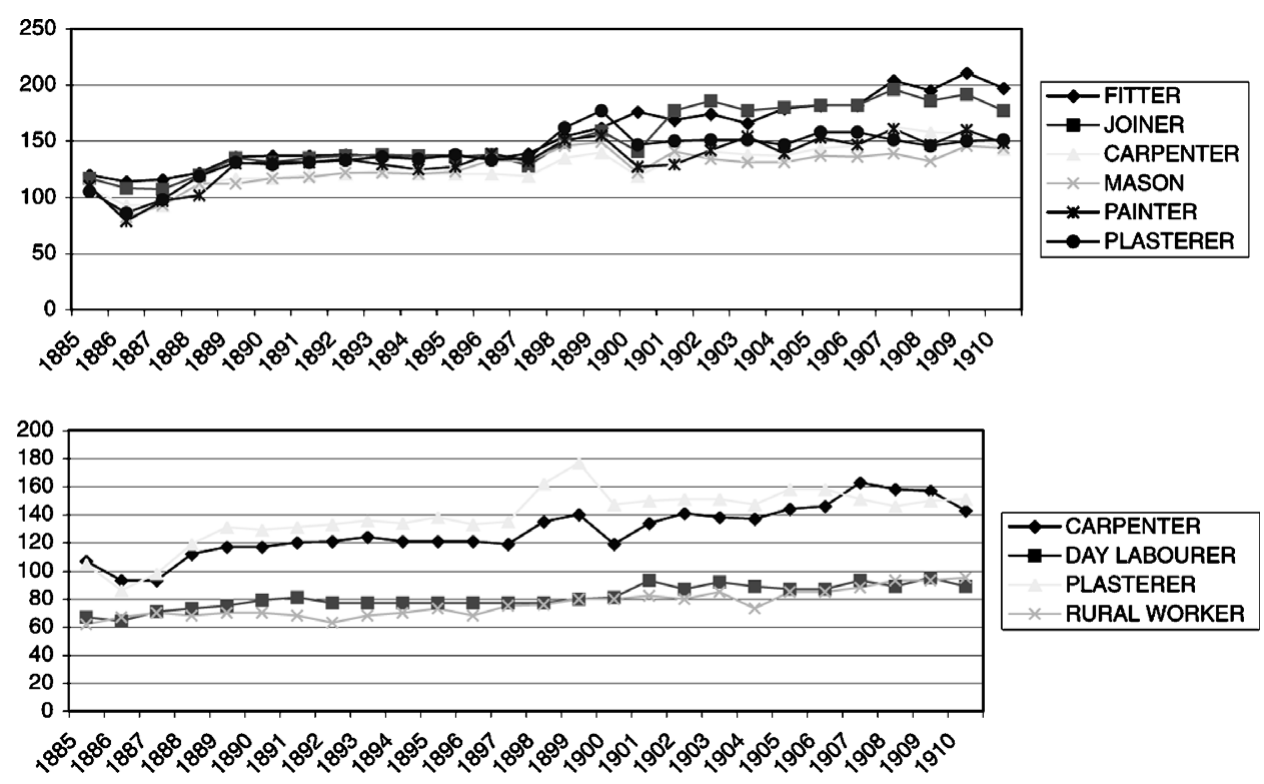

Figure 3. Daily wage by skill level, St Petersburg, I884-I9Io

Source: Rykachev (I9II).

some of the building trades (carpenter and plasterer as examples) and day labourer and rural worker. ${ }^{19}$

The rise in skill differentials shows the changing qualifications of labour in St Petersburg. Rashin argued that peasants were acquiring skills and new identities as workers, and this must have been the case, since the population increase in this period was due almost entirely to peasant immigration. ${ }^{20} \mathrm{On}$ average in Russian cities, the proportion of peasants in the urban population rose from 20 per cent in $186 \mathrm{I}$ to 38 per cent in 1897 ; in Moscow and $\mathrm{St}$ Petersburg in 1902, 68 and 67 per cent were peasants, while the indigenous population growth between I86I and I9I3 was 6 per cent in Moscow and 2.5 per cent in St Petersburg. ${ }^{21}$ It is important to point out that by 19I2, in both cities, peasant workers were, on the whole, literate ( 86 per cent of male workers in I9I2 in St Petersburg were literate, and 8I in Moscow). Literacy in Russia in general rose from I9 per cent in I869 to 26 per cent in I883 to 35 per cent in 1907 and to 43 per cent in $1917 .{ }^{22}$ Literacy cannot be used as a proxy for skills, but it represents a general level of development that does not

\footnotetext{
I9 Rykachev (I9II).

20 Rashin (I956, p. I I6).

${ }^{21}$ Both rates of growth were well below the average for 50 gubernii of Russia (I4.9 per cent) (Rashin I956, pp. I2I-I4I, I67-8, I87-8, 2I7-I8).

${ }^{22}$ Mironov (I99I, p. 82).
} 
fit the 'backwardness' thesis, and it shows that St Petersburg seems similar to Moscow in the quality of its labour supply.

\section{Measurement and estimation}

\section{I. Data}

The most often used source for Russian scholarship on Russian industrial wages beginning in the 1880 s is the Factory Inspectorate. It was the main source for Tugan-Baranovsky (1922) for selected dates. Vainshtein (I960, 1967) and others compiled wage rates from regional archival records from the late I880s and I890s; Strumilin (I960) published wage series for individual factories. ${ }^{23}$ There are no aggregated industrial series. Other Soviet economic historians did not work on wage dynamics or other factor prices, nor did they provide any historical price series, apart from indices created (for the I880s through I913) in the I920s, discussed below, in their extensive quantitative research.

In the post-Soviet era, the available materials and unpublished resources on factory labour are now being re-examined for a regional economic history of tsarist Russia. This work undertaken by Borodkin and Valetov (I999) is only beginning. For our study, we used wage series published in Viestnik Finansov in I9I I by A. Rykachev, who gives information on daily nominal wages for unskilled and semi-skilled construction workers (six occupations) in St Petersburg.

Historical agricultural wages are more readily available. Strumilin's real wage series (1960) is countrywide aggregated figures, based on 1920 indices. For this study, the level of aggregation is excessive; the alternative source is local government (zemstva) survey data. These we used from surveys designed by the Statistical Department of the Ministry of Agriculture and carried out by zemstva officials in all gubernii of Russia beginning in I88I. ${ }^{24}$ The survey had 23 questions, of which three were useful for our research:

(4) What was the wage rate for workers during the mowing season (payment per desiatina of standard quality hay mowed, a daily wage both with and without the provision of food for mowing and gathering - both men's and women's wage per pud [36.I I lbs] of gathered hay, and so forth)? Was there any insufficiency in the supply of labour?

(Io) What was the wage rate during the harvest and planting of winter wheat (it is necessary to indicate whether pay included food)?

(II) What was the annual wage rate for male, female and adolescent workers?

\footnotetext{
${ }^{23}$ For example, Kolomna machine tools factory, see Strumilin (I960, p. II).

${ }^{24}$ MGZU SKh (I88I-I9I9).
} 
Every year, the zemstva compiled the responses from several hundred farms hiring labour surveyed in each guberniia. The number sampled grew each year for the 13 districts of Moscow guberniia, for example, from 25I landowners (including peasant households that hired labour) in 1884 to 517 in 1906.

We used the daily wage paid to farm labourers (an average for spring planting, summer mowing and harvesting). This means we did not capture the 'shadow supplementary wage' for off-season work in winter in nonagricultural employment. Typically, this might be a substantial sum (for Moscow 37.2 per cent of household earnings in I884 and 42.7 per cent in 1906). ${ }^{25}$ However, our estimate was based on the agricultural wage which competed against the contract offered in St Petersburg for largely seasonal labour, the rural alternative in the relatively infertile non-Black Earth zone. From these sources, we derive a wage series for I884-1910.

\subsection{Cost-of-living adjustment}

Adjusting for cost of living is less feasible in the study of the wage gap than it is for the study of urban wages alone. This is in part because of the high level of aggregation required for urban and rural wages in the ratio. Even for a regional study, however, there are reasons why the cost-of-living estimates for Russian tsarist history would be misleading.

Separate cost-of-living adjustments would have to be available for rural and urban sectors. Preference patterns differ - there are different price and income elasticities of demand for the same products by individuals in different sectors. ${ }^{26}$ Cost-of-living adjustments in the urban sector, assuming that price and household budget information is available, include non-cash payments, hours, working conditions and wage-earning opportunities for other family members. Agricultural earnings should include estimates of the average value of extra wages during harvest, and board and free food at harvest time. For agriculture, such estimates are rarely available. George Grantham (1989) writes about the mis-measurement of real agricultural wages for French history, where price deflators use widely traded (rather than non-traded) agricultural commodities leading to a discrepancy of as much as 25 to 33 per cent. ${ }^{27}$

\footnotetext{
MGZU SKh (I884; 1906).

${ }^{26}$ Cheetham, Kelley and Williamson (I974); Jones (I975).

${ }^{27}$ Grantham (1989, p. 66): 'There is no meaningful general price of non-traded foods because they were usually not profitable to ship and because crops such as potatoes, maize, and chestnuts could be grown by women and children whose alternative employments within agriculture were generally poorly paid. At the margin, the price of traded agricultural commodities - vital as it was for all those who, like the woodcutters and iron workers and rural weavers, had to buy their food in markets - overstates the true
} 
For Russian wages, five deflators are available, but all of them cover only urban wholesale and retail prices. ${ }^{28}$ We find that Strumilin's agricultural wage index, using the Podtiagin index, after first removing commodities likely to be purchased only by urban labourers, is still not sufficiently close to the real cost of living to use. ${ }^{29}$

Nominal wages, therefore, are necessary, and they are also of some importance. Nominal wages, as De Vries (1994) observes, are the actual payment to labour, and they directly affect the cost of production and demand for labour. ${ }^{30}$ Empirically, moreover, as Hatton and Williamson (1992) found, 'the crude cost-of-living deflators do not seem to have a significant impact on the wage-gap time series' (p. 275, and note 30). Although cost-of-living deflators would be expected to account for a considerable part of the gap in earnings, they do not use them for rural wages in the US before $1913 .{ }^{31}$

We acknowledge, of course, serious potential distortions from using nominal wages. ${ }^{32}$ We can adjust only partly, for example, for seasonality. Russian agricultural wages were seasonally varied, more than for western Europe and the US. The spring planting began in March only in the Black Earth zones to the south, and the climatic conditions permitted only two crops annually, winter and spring. When the milling was completed in the first weeks of October, producers had a long winter season to supplement their earnings in agriculture by crafts, carting and industrial labour, whose remuneration varied considerably. The surveys upon which one must rely, taken in the I880 by the Ministry of Agriculture, covered only work from late spring through fall, the seasonal pay for each of the three major tasks (planting, harvesting and mowing) carried out between April and October. The off-farm earnings in the winter cannot reliably be estimated. This problem is important because the migration models upon which all economic

cost of subsistence for the mass of country people, who had a variety of non-market sources of subsistence.'

${ }^{28}$ The two for retail prices (the Petersburg index of the Institute of Economic Research and the Petersburg and Moscow 'Kokhn' index) use weights based on the structure of average budget expenditures of industrial workers, and they are correlated. A third price deflator is the Podtiagin wholesale price index for 66 commodities for Moscow and St Petersburg taken from the Ministry of Trade and Industry's annual Survey of Commodity Prices in Major Russian and Foreign Markets. The Podtiagin differs from the other two indices somewhat: there is a steeper drop in price level after 1900 for the Podtiagin index (figures in the appendix show the difference in wage gap measured by the Kokhn and Podtiagin indexes). The Podtiagin index fluctuates more than the other two, especially during the rise in prices after 1905. For a discussion of these indices, see Gregory (I982, pp. 20I-3).

29 Strumilin (I960, p. 89).

${ }^{30}$ De Vries (I994, p. 50).

${ }^{3 \mathrm{I}}$ Hatton and Williamson (1992, n. 30, p. 293).

${ }^{32}$ See Hatton and Williamson (1992) for a review of the economic literature on the nature of those distortions. 


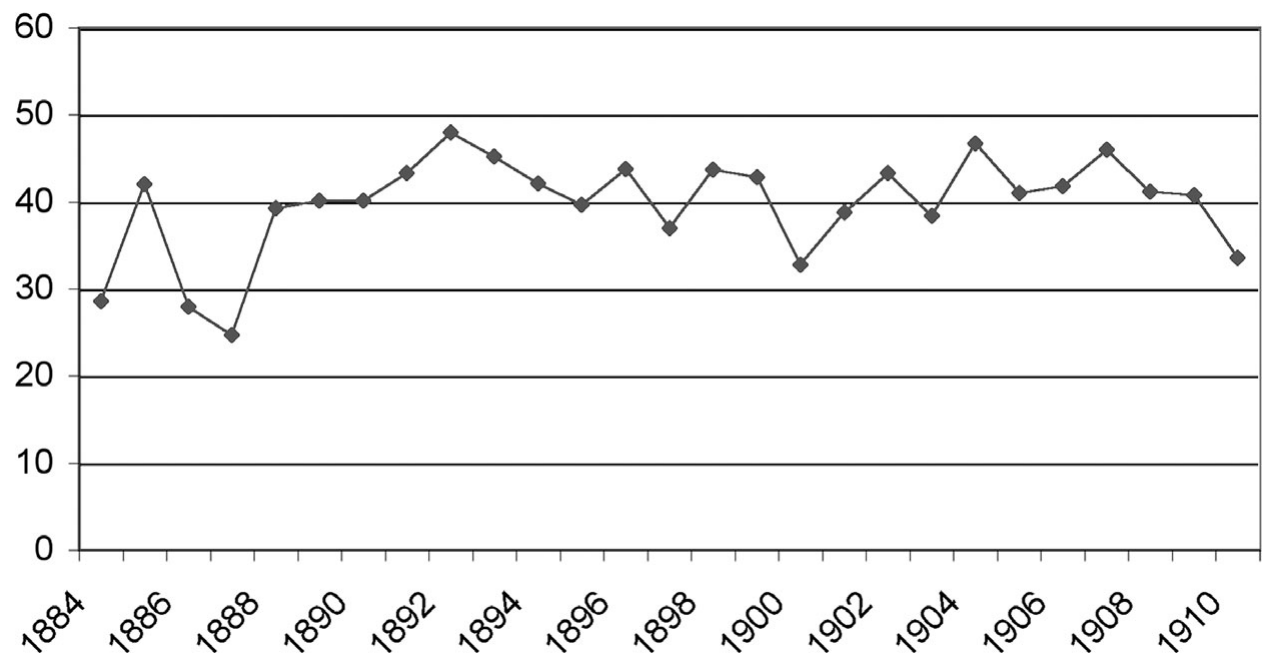

Figure 4. Nominal wage ratio (rural/urban), St Petersburg

Source: See Appendix I.

analyses of the wage gap are based estimate expected rather than actual pay, and, for the agricultural sector, this would have included with certainty the jobs held in the winter months.

We present in Figure 4 the ratio of daily nominal wages for rural day labourers in the guberniia and urban construction workers in St Petersburg, where they tended to find their employment. Figure 4 shows the wage ratio between semi-skilled (carpenters) urban labourers and agricultural labour. After some volatility, the wage ratio shows a low stable gap. Agricultural wages remain between 25 and 48 per cent of urban wages for the duration (the mean is about 40 per cent). The rough magnitude of the gap is similar to that in western countries for periods of industrialisation, although wider than in early nineteenth-century England, where rural wages lagged by only I3 per cent, but similar to the American North, where the gap fluctuated between 29 and $4 \mathrm{I}$ per cent, and in the I890s rose to 50 per cent. ${ }^{33}$

The relatively stable wage gap for this region suggests that the movement of peasants was not unduly restrictive during bursts of urban industrial growth and recession; only moderate peaks appear in Figure I. The variance is well short of confirming constrained industrialisation, sluggish labour response, that is, bottlenecks for manufacturing in St Petersburg. We conclude that the restrictive laws had little real impact on rural migratory labour, at least in this region.

${ }^{33}$ Hatton and Williamson (I992, p. 267). 


\subsection{Estimation approach}

We use an error correction model to detect lagged convergence, when controls are made for known demand-side shocks to which the several time series may commonly respond. Most series that follow an upward trend are correlated with each other, thus such correlations can easily be spurious, and it is important to avoid generalising from a false statistical base.

Hatton and Williamson (1992) test the existence and magnitude of wage distortions for the US for I890 to I94I. They found for that era large fluctuations in the wage ratio. Up to the end of World War I it rose and then collapsed afterwards, through the I930s. Using a disequilibrium version of the Todaro model (1969), they found that the coefficients on the wage ratio and the employment rate were of equal magnitude for the entire period of their study. When a lagged wage ratio was included, the agricultural wage responded very little to it, showing that migrants in the interwar period were responsive primarily to current labour-market signals; the coefficient on lagged migration was small and insignificant. Among demand-side factors, they found terms of trade to be important as a determinant of the farm wages. In general, a rise in the real non-farm wage, taken as exogenous, raised the farm wage while it increased the wage gap (reduced the wage ratio) and generated urban unemployment. An immigrant-augmented labour force also widened the gap, lowering the wage ratio. ${ }^{34}$

Boyer and Hatton (1994) developed an error correction model by which they assessed the degree of long-run integration between markets. With a simple model of labour demand in each market, they gained a better estimation of the relationship between the two markets. They tested for the following relationship in the data-generating process (dgp):

$$
\Delta \log W_{i t}=d_{\circ}+d_{\mathrm{I}} \Delta \log W_{j t}+d_{2} \log \left(W_{i} / W_{j}\right)_{t-\mathrm{I}}+v_{t}
$$

where $W_{i t}$ is the wage indexed by location and time. Their finding, that the coefficient $d_{I}$ on the $\Delta \log W_{j t}$ term is positive and significant, is explained as the effect of common shocks, presumably demand-side effects due to the fluctuations in agricultural prices and variations in weather conditions. However, the coefficient on the lagged wage ratio showed only weak effects.

Our analysis aimed to test model (I) on Russian data. We first used a test for co-integration as a measure of a long-run relationship between two labour markets. We understood that Boyer and Hatton's findings are only weak empirical support for this relationship. We anticipated that our test for co-integration in the Russian case was also likely to show weak results. We have a small number of variables and short length of historical period. This imposes constraints on a general structural model and on tests for causal significance.

${ }^{34}$ Hatton and Williamson, (I992, p. 292). 
The most widely used method for constructing the co-integration test is the maximum likelihood based Johansen (1988) and Johansen-Juselius (I990) test, which tests the co-integrating relations of vector autoregressive (VAR) models. This method requires that the variables in VAR must be of equal order of integration, and it determines the number of co-integrating vectors based on the maximal eigenvalue and trace test. If the null hypothesis of no co-integrating vector is rejected, the error correction model (ECM) is applied. We use an alternative method, the ordinary least squares (OLS) based autoregressive distributed lag (ARDL), or the bounds test approach, to co-integration developed by Pesaran and Shin (1995b), with several considerations.

First, the ARDL to co-integration allows variables of different order of integration, that is, irrespective of whether they are $\mathrm{I}(\mathrm{O}), \mathrm{I}(\mathrm{I})$ or fractionally integrated. Secondly, it provides robust results in small sample size for better properties. Furthermore, the ECM integrates the short-run dynamics, which are derived from ARDL, through a linear transformation with long-run equilibrium without losing long-run information. Also this approach takes sufficient numbers of lags to capture the dynamic behaviour of the data variables. The objective was to see if, when the wage gap was large in the previous year, farm wages would rise with a lag in response to industrial wages.

\section{Empirical results}

We refer, as a main result, to Figure 5 to show that both rural and urban daily wages in St Petersburg are moving rather smoothly. Such behaviour is compatible with integrated processes. The rural wage series appears relatively stable, as was true in British history between 1880 and 1890.35 Our Russian rural series fluctuated around the harvest failure of I89I and moves upward after 1897, presumably the combined effect of the weakening of restrictions on out-migration in the I890s and the movement of urban wages. Careful inspection of the urban wage suggests that this series went through several different evolutions particularly after I897, probably linked to the introduction of labour legislation restricting hours of work. Allen (1994) confirms that urban wages are more variable empirically than would be predicted from the development literature and the Todaro model. ${ }^{36}$

We do not find sustained constant high urban wages, as theory predicts, with agricultural wages rising with a lag to catch up. Moreover, it is important to note that after the Stolypin land reforms in 1906, in principle an event of major significance in encouraging rural emigration, neither urban nor rural wages seem to show any effects.

35 Boyer and Hatton (I994, p. 96).

${ }^{6}$ Allen (I994, pp. I I9-20). 


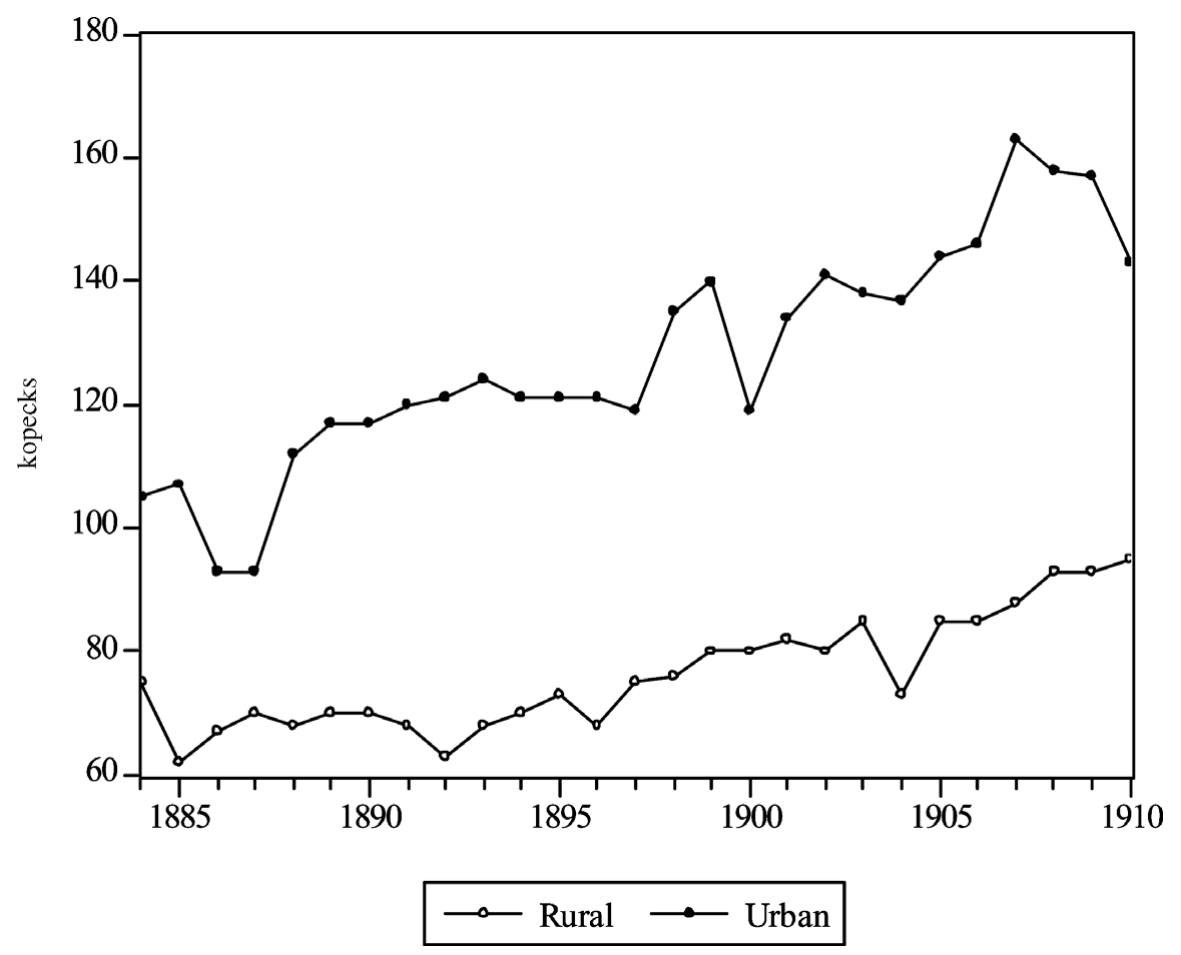

Figure 5. Rural and urban daily wages, St Petersburg, I884-I9IO

Source: See Appendix I.

Table 2. Sample statistics

\begin{tabular}{|c|c|c|c|c|c|c|}
\hline & \multicolumn{2}{|c|}{ I884-I9IO } & \multicolumn{2}{|c|}{ I884-I896 } & \multicolumn{2}{|c|}{ I897-I9IO } \\
\hline & $\begin{array}{l}\text { Rural } \\
\text { wages }\end{array}$ & $\begin{array}{l}\text { Urban } \\
\text { wages }\end{array}$ & $\begin{array}{l}\text { Rural } \\
\text { wages }\end{array}$ & $\begin{array}{l}\text { Urban } \\
\text { wages }\end{array}$ & $\begin{array}{l}\text { Rural } \\
\text { wages }\end{array}$ & $\begin{array}{l}\text { Urban } \\
\text { wages }\end{array}$ \\
\hline Mean & 76.4 & I27.6 & 68.6 & II 3.2 & 85.6 & I4I. \\
\hline Maximum & 95.0 & I63.0 & 75.0 & $\mathrm{I} 24.0$ & 95.0 & I63.0 \\
\hline Minimum & 62.0 & 93.0 & 62.0 & 93.0 & 73.0 & II9.0 \\
\hline Std. Dev. & $9 \cdot 3$ & I 8.3 & $3 \cdot 5$ & I0.6 & 6.9 & 12.9 \\
\hline Jarque-Bera & I. 7 & 0.3 & O.I & 2.2 & 0.7 & O.I \\
\hline Probability & 0.4 & 0.8 & 0.9 & 0.3 & 0.7 & 0.9 \\
\hline Observations & 27.0 & 27.0 & I3.0 & 13.0 & $\mathrm{I} 4.0$ & $\mathrm{I} 4.0$ \\
\hline
\end{tabular}

The full sample runs from I884 to I9IO and we consider an intermediate date 1897 . Table 2 presents sample statistics for the entire period as well as for the subperiods.

Alternative tests are used, further, to continue the exploration for a long-run relationship between the two series, which would show distinctive evidence of functioning markets in St Petersburg. Using EViews 5.I, we 
Table 3. Unit-root tests for full sample

\begin{tabular}{|c|c|c|c|c|c|c|c|c|}
\hline & \multicolumn{7}{|c|}{$\mathrm{ADF}$} & \\
\hline & $\mathrm{s} \alpha_{\mathrm{o}}$ & $\mathrm{t}_{\alpha \circ}$ & $\alpha_{\mathrm{I}}$ & $\mathrm{t}_{\alpha \mathrm{I}}$ & $\alpha_{2}$ & $\mathrm{t}_{\alpha 2}$ & $\mathrm{t}_{\beta \mathrm{k}}$ & \\
\hline$\overline{\mathrm{W}}_{\mathrm{At}} \sim \mathrm{I}(\mathrm{I})$ & -17.405 & $-2.02 \mathrm{I}$ & -0.029 & -0.125 & 0.266 & I.686 & -2.633 & \\
\hline \multirow{3}{*}{$\mathrm{W}_{\mathrm{Mt}} \sim \mathrm{I}(\mathrm{I})$} & $104.5 \mathrm{I} 2$ & 4.409 & 2.586 & 4.042 & -1.176 & -4.349 & I.927 & \\
\hline & \multicolumn{3}{|c|}{ Phillips-Perron Tests } & \multicolumn{2}{|c|}{$\begin{array}{l}\text { KPSS Tests } \\
(\sim \mathrm{I}(\mathrm{o}))\end{array}$} & & & \\
\hline & $\mathrm{PP}(\tau)$ & $\mathrm{PP}(\mu)$ & PP & $\overline{\eta_{\tau}}$ & $\eta_{\mu}$ & & & \\
\hline$\overline{\mathrm{W}}_{\mathrm{At}}$ & -0.355 & 4.068 & 2.398 & 0.174 & 0.650 & & & \\
\hline $\mathrm{W}_{\mathrm{Mt}}$ & -3.498 & $-\mathrm{I} .209$ & I. 677 & 0.216 & 0.716 & & & \\
\hline \multirow[t]{3}{*}{$\mathrm{I} \%$} & -4.297 & -3.670 & -2.644 & 0.216 & 0.739 & & & \\
\hline & \multicolumn{8}{|c|}{ Ng-Perron Tests } \\
\hline & $\overline{M Z} \alpha(\tau)$ & $\operatorname{MZt}(\tau)$ & $\operatorname{MSB}(\tau)$ & $\operatorname{MPT}(\tau)$ & $M Z \alpha(\mu)$ & $\operatorname{MZt}(\mu)$ & $\operatorname{MSB}(\mu)$ & $\operatorname{MPT}(\mu)$ \\
\hline$\overline{\mathrm{W}}_{\mathrm{At}}$ & $-2.59 \mathrm{I}$ & -0.663 & 0.256 & 21.197 & $3 \cdot 330$ & I. 488 & 0.447 & 25.560 \\
\hline $\mathrm{W}_{\mathrm{Mt}}$ & -12.295 & -2.383 & 0.194 & $7.9 \mathrm{II}$ & -2.394 & -0.978 & 0.408 & 9.533 \\
\hline I $\%$ & -23.800 & -3.420 & 0.143 & 4.030 & -13.800 & -2.580 & 0.174 & 1.780 \\
\hline
\end{tabular}

Notes: The number of lags $(k)$ in the ADF regression is one.

$\mathrm{PP}(\tau), \mathrm{PP}(\mu)$ and $\mathrm{PP}$, are tests of the unit root null hypothesis where the test regression contains a constant and a trend, a constant and no deterministic components, respectively. A similar notational convention is followed for the Ng-Perron tests. KPSS tests of stationarity around a non-zero mean and a linear trend are displayed as $\eta_{\tau}$ and $\eta_{\mu}$. All the tests follow $\sim \mathrm{I}(\mathrm{I})$ except KPSS which follows $\sim \mathrm{I}(\mathrm{O})$.

conduct several unit-root tests, as shown in Table 3. First, the test strategy adopted follows the test methodology described in Dolado, Jenkinson and Sosvilla-Rivero (1990). We test the rural and urban wage series (respectively $w_{A}, w_{M}$ ) for integration using the Augmented Dickey-Fuller (ADF) regression with a constant and a trend since both of the series exhibit absolute time trends, as can be seen in Figure 5. The optimal lag length of $\mathrm{ADF}$ test for both series is one according to the Akaike information criterion.

$$
\begin{aligned}
& \Delta w_{A t}=\alpha_{\circ}+\alpha_{\mathrm{I}} t+\alpha_{2} w_{A t-\mathrm{I}}+\sum_{j=\mathrm{I}}^{K} \beta_{j} \Delta w_{A t-j}+u_{t} \\
& \Delta w_{M t}=\alpha_{\circ}+\alpha_{\mathrm{I}} t+\alpha_{2} w_{M t-\mathrm{I}}+\sum_{j=\mathrm{I}}^{K} \beta_{j} \Delta w_{M t-j}+u_{t}
\end{aligned}
$$

Testing both series first in levels, the t-statistic of the rural wage series of $\mathrm{I} .686$ was much greater than the critical value of $-4.3 \mathrm{IO}$ at a I per cent significance failing to reject the null hypothesis of non-stationarity. While the urban wage series showed a t-statistic of -4.349 slightly greater than the critical value of -4.374 at a I per cent significance with a probability of $\mathrm{I} .06$ per cent, but lower than the critical value of -3.603 at a 5 per cent significance. We accept the null hypothesis of non-stationarity at I per cent. Therefore moving the tests to first differences, we find that rural wages follow 
Table 4. Test for structural break ( $H_{0}$ : no structural break in 1897)

\begin{tabular}{llll}
\hline \hline F-statistic & $0.36785 \mathrm{I}$ & Prob. F(3,I8) & 0.777079 \\
\hline Log likelihood ratio & $\mathrm{I} .428064$ & Prob. Chi-Square(3) & 0.698970 \\
\hline \hline
\end{tabular}

Chow Breakpoint Test: 1897

a random walk as the t-statistic of -3.462 is lower than the critical value at Io per cent significance with 6.35 per cent probability, the null can be rejected and this indicates that the rural wage series is following an I (I) process. The t-statistic of the urban wage series of -5.190 is much smaller than the critical value at a I per cent significance, therefore the null could be rejected indicating that the urban series may contain one root and is of integrated order one I (I). There were some tests we were not able to perform due to the size of our sample. For instance, the Elliot, Rothenberg and Stock (1996) (ERS) test, generalized least squares (GLS) local detrending test, could not be performed as the test-critical values are calculated for 50 observations while the size of our sample is 29 observations. We also found that when applying the Phillips-Perron (1988) (PP) and Ng and Perron (200I) tests to our time series, the results are consistent with the ADF test to accept/reject the null hypothesis of non-stationarity.

For St Petersburg, in view of the sustained growth in urban wages and the relatively stable agricultural wages, we first tested for a possible structural break in 1897 , the year of major labour legislation and the year following a shift in price conditions in Europe. A CHOW test, however, does not reveal a breakpoint in 1897 and the null hypothesis of no structural break could not be rejected (Table 4). Also the cumulative sum of the squared residuals does not indicate a break point in I897 (Figure 6).

In log-linear form the long-run equilibrium of rural and urban wage is formulated as an ARDL ( $\mathrm{I}, \mathrm{I})$ model:

$$
\log w_{A t}=a_{\circ}+a_{\mathrm{I}} \log w_{A t-\mathrm{I}}+b_{\circ} \log w_{M t}+b_{\mathrm{I}} \log w_{M t-\mathrm{I}}+e_{t}
$$

where $w_{A}=$ the agricultural wage and $w_{M}=$ the industrial wage, detrending the variables, and $e_{t}$ is an error term.

Given the integrated nature of the time series, the first difference of equation (2) is outlined by the following equation:

$$
\Delta \log w_{A t}=a_{\circ}+b \Delta \log w_{M t}+\gamma_{A} \log w_{A t-\mathrm{I}}+\gamma_{M} \log w_{M t-\mathrm{I}}+e_{t}
$$

where $\quad \Delta \log w_{A t}=\log w_{A t}-\log w_{A t-\mathrm{I}}, \quad \Delta \log w_{M t}=\log w_{M t}-\log w_{M t-\mathrm{I}}$, $\gamma_{A}=a_{\mathrm{I}}-\mathrm{I}$ and $\gamma_{M}=b_{\mathrm{o}}+b_{\mathrm{I}}$.

We test whether there exists a co-integrated relation between the variables, that is, the null hypothesis is $\gamma_{A}=\gamma_{M}=0$ against the alternative $\gamma_{A} \neq 0$ and $\gamma_{M} \neq 0$, which indicates non-existence of co-integration by applying Schwarz Bayesian Criterion (SBC) and the mean of F-test. We found that, in St Petersburg, there was evidence of one co-integrating equation (Table 5). 


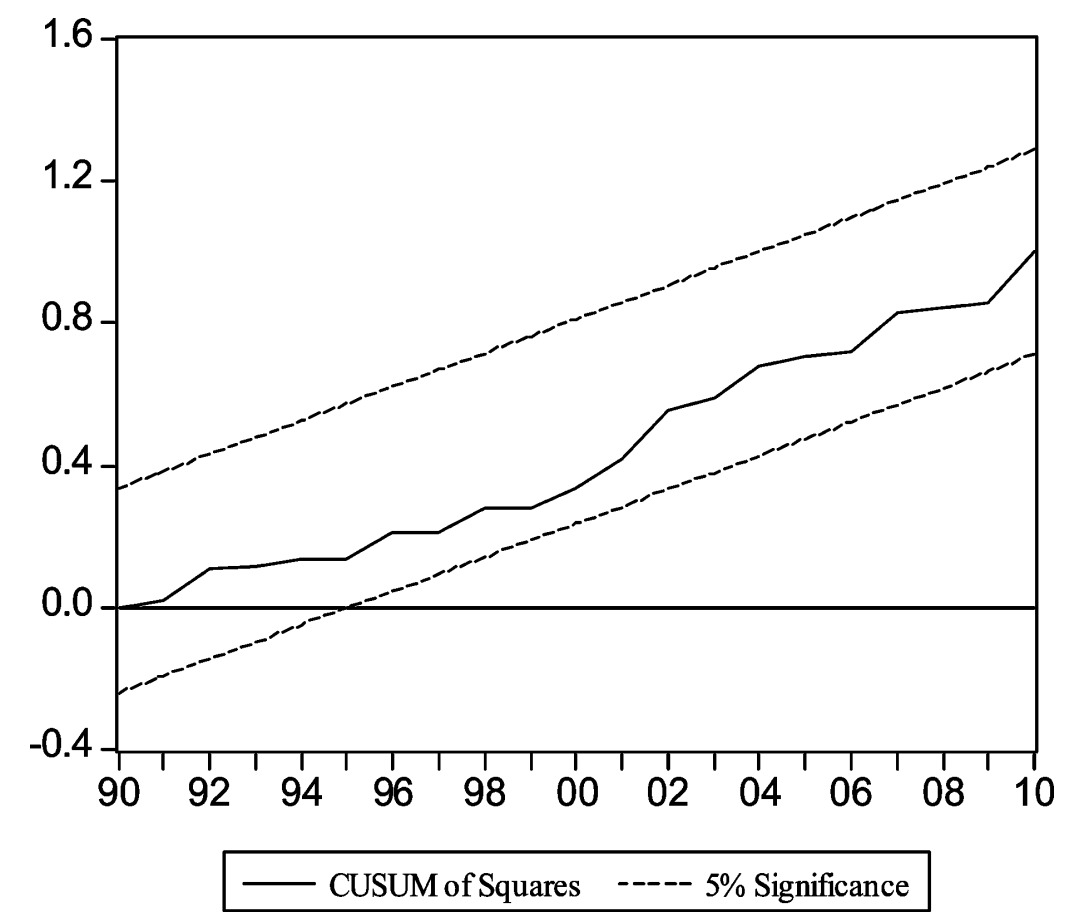

Figure 6. Cumulative sum of squared recursive residuals

Source: See Appendix I.

We can now develop an error correction model:

$$
\begin{aligned}
\Delta \log w_{A t}= & a_{\circ}+b \Delta \log w_{M t}+\gamma_{A}\left(\log w_{A t-\mathrm{I}}-\log w_{M t-\mathrm{I}}\right) \\
& +\left(\gamma_{M}+\gamma_{A}\right) \log w_{M t-\mathrm{I}}+e_{t}
\end{aligned}
$$

Then we test the null hypothesis $-\gamma_{A}=\gamma_{M}$, that is $\mathrm{I}-a_{\mathrm{I}}=b_{\circ}+b_{\mathrm{I}}$, and the low statistic value and relatively high probability shows the null is accepted (Table 6). Finally, the following short-run adjustment model can be estimated by OLS:

$$
\Delta \log w_{A t}=a_{\circ}+b \Delta \log \left(w_{M t}\right)+\gamma \log \left(w_{A} / w_{M}\right)_{t-\mathrm{I}}+e_{t}^{37}
$$

37 Proof of ECM:

Let $y_{t}=\log w_{A t}$ and $x_{t}=\log w_{M t}$

$y_{t}=a_{\mathrm{o}}+a_{\mathrm{I}} y_{t-\mathrm{I}}+b_{\mathrm{o}} x_{t}+b_{\mathrm{I}} x_{t-\mathrm{I}}+e_{t}$

$\Delta y_{t}=a_{\circ}+\left(a_{\mathrm{I}}-\mathrm{I}\right) y_{t-\mathrm{I}}+b_{\circ} \Delta x_{t}+\left(b_{\circ}+b_{\mathrm{I}}\right) x_{t-\mathrm{I}}+e_{t}$

$=a_{\circ}+\gamma\left(y_{t-1}-x_{t-1}\right)+b_{\circ} \Delta x_{t}+\lambda x_{t-\mathrm{I}}+e_{t}$

where $\gamma=a_{\mathrm{I}}-\mathrm{I}$ and $\lambda=b_{\mathrm{o}}+b_{\mathrm{I}}+a_{\mathrm{I}}-\mathrm{I}$

We impose restriction $\mathrm{I}-a_{\mathrm{I}}=b_{\mathrm{o}}+b_{\mathrm{I}}$, the ECM model is

$\Delta y_{t}=a_{\circ}+\gamma\left(y_{t-\mathrm{I}}-x_{t-\mathrm{I}}\right)+b_{\circ} \Delta x_{t}+e_{t}$ 
Table 5. Bounds test for equation ( $3 a$ ) ( $H_{o}$ : no co-integration)

\begin{tabular}{lccc}
\hline \hline F-statistic (2,23) & $35.72 \mathrm{I} 6$ & Prob. & 0.000 \\
\hline \hline Table 6. Coefficients & test $H_{\circ}: \mathrm{I}-a_{\mathrm{I}}=b_{\mathrm{O}}+b_{\mathrm{I}}$ & \\
\hline \hline F-statistic (I,22) & $\mathrm{I} .2388$ & Prob. & 0.2777 \\
Chi-square (I) & $\mathrm{I} .2388$ & Prob. & 0.2657 \\
\hline \hline
\end{tabular}

Table 7. Error correction model for agricultural wages, St Petersburg (I884-I9IO)

\begin{tabular}{llll}
\hline \hline Regressor & Coefficient & StandardError & T-Ratio[Probability] \\
\hline CONSTANT & $-0.232 \mathrm{I}$ & 0.0828 & $-2.804 \mathrm{I}[0.0 \mathrm{IOI}]$ \\
$\Delta \log \left(w_{M_{t}}\right)$ & $0.169 \mathrm{I}$ & 0.1904 & $0.8878[0.3838]$ \\
$\log \left(w_{A} / w_{M}\right)(-\mathrm{I})$ & -0.4649 & $0.157 \mathrm{I}$ & $-2.9602[0.0070]$ \\
\hline \hline
\end{tabular}

R-Squared $=0.2802$ S.E. of regression $=0.064316$ Schwarz criterion $=-2.396689$ F-statistic $=4.4768 \mathrm{I}$ I [0.022798] Durbin-Watson stat $=2.186733$ Ljung-Box $\mathrm{Q}(\mathrm{I} 2)=8.7475[0.724]$

Table 7 presents the estimation results. The negative sign on the coefficient of the lagged wage ratio, i.e. $\gamma$, the error correction term, is highly significant, which shows a fairly large impact in the right direction, that is, presumably, the widening of the gap produced a response in the rural wage. Approximately 46 per cent of disequilibria from the previous shock converge back to the long-run equilibrium. The regression of equation (3c) fits at $R^{2}=28.02$ per cent, which implies that the impact of the urban wage on the rural wage could not be long-term disequilibria - that it will be corrected in a short period of time.

From this test of equilibrium properties in St Petersburg, we can conclude that there is evidence in labour markets of the working of market forces. Even in this northern, relatively harsh environment for agriculture, with increasing trade, gains in agriculture had been such as to allow rural wages to move flexibly in response to the wage ratio.

\section{Conclusion}

The significance of the tests in Tables 5 to 7 is a clear result for the question we posed: is the disequilibrium model of rural/urban labour markets, devised for explaining US history, useful in exploring controversy over Russian agrarian potential in the late tsarist period?

Our test showed that the model was indeed generalisable. Preliminary examination had shown that the gap was relatively stable, except for the period of the recession in 1908. It averaged roughly 35 per cent; this suggests that the wage gap was comparable both in stability and level to other historical experiences in industrialisation. Our model estimation results showed that rural wages in Russia were flexible. This is in contrast with the conclusions 
of Strumilin, who found sticky nominal rural wages across the country throughout the period, a conclusion underlying the pessimistic findings on the Russian pre-revolutionary rural economy by Allen (2003).

We began this study on the basis of aggregated all-Russian data for the period I 884-I9IO and found evidence of long-run convergence in rural/urban labour markets (Borodkin and Leonard 2000), but we decided to go to the regional level because of striking regional divergence over vast territory and our search for short-run properties. Using regional data, we now show some evidence of convergence for the rapidly industrialising region of $\mathrm{St}$ Petersburg. The response by both the rural and urban wages series to the same demand stimuli and to the lagged wage gap can be seen over our critical period of growth. This, of course, is not a full test of the Todaro model. We have no unemployment data, and we cannot assume wage equalisation or countrywide dynamics. The differences in production structure between the two capitals, St Petersburg and Moscow, make it difficult to assume a comparability of labour-market conditions. In regions distant from coastal areas and from the two capitals, poverty and isolation from world markets, and steeper costs of transportation, may make labour-market conditions there even less comparable.

However, results show significant potential for the approach. We are confident that these results fit the institutional history of I890s, less well known than that of the later parliamentary period. Local market structures were rapidly strengthening, well before the revolution of 1905. Ministry programmes for agricultural extension were developed; the substantial empowerment of provincial government helped spread knowledge, financial instruments and even the use of agricultural machinery..$^{38}$ For the years from 1907 to 1912, the period of the Third Duma, policies embracing universal primary education and security of property rights built on earlier institutional expansion. Close studies might show, as a particular source of economic growth in areas near regional capitals, the contribution of spillovers to seasonal migration of 'sending communities', where men worked in nearby urban areas and women tended the land. Migratory cycles would provide data on economic benefit. ${ }^{39}$

Evidence of economic trends also lies in nominal wage segmentation in the building trades in St Petersburg, where on average, skilled labour earned wages about 95 per cent higher than those paid to the unskilled (see Figure 3). This is a figure roughly equivalent to the gap observed in developing countries and in other countries experiencing industrialisation in the nineteenth century, and well over the gap in the US in the $1890 .^{4 \circ} \mathrm{In}$

\footnotetext{
${ }^{38}$ Leonard (forthcoming).

39 See Unger (2005) for empirical findings on Mexican sending municipalities that experience migratory intensity.

$4^{\circ}$ Hatton and Williamson (I99Ib, p. 382).
} 
conclusion, our findings go in the direction of the growing understanding from quantitative research by economic historians that the positive view of economic advancement in the period is not built on shaky foundations. There was no deficit of unskilled and semi-skilled labour in this region. Industrialisation in pre-revolutionary Russia had potential for continued expansion.

\section{Acknowledgements}

We appreciate comments on an early version by Paul David and Richard Sutch, who advised a regional approach to this issue, and by Timothy Hatton, Paul Gregory, Knick Harley, Ning Zeng and anonymous reviewers in our revisions.

\section{References}

ALLEN, R. C. (1994). Real incomes in the English-speaking world, I879-1913. In G. Grantham and M. MacKinnon (eds.), Labour Market Evolution: The Economic History of Market Integration, Wage Flexibility and the Employment Relation. London and New York: Routledge, pp. 107-38.

Allen, R. C. (2003). Farm to Factory: A Reinterpretation of the Soviet Industrial Revolution. Princeton, NJ: Woodstock: Princeton University Press.

ANFImov, A. M. (I980). Krest'ianskoe khoziaistvo evropeiskoi Rossii, I88I-I904. Moscow: Nauka.

Anfimov, A. M., Danilova, L. V. and Koroleva, S. I. (1993). Sistema gosudarstvennogo feodalizma v Rossii: sbornik statei. Moscow: Rossiiskaia Akademiia Nauk RF.

BARKAI, H. (1973). The macro-economics of tsarist Russia in the industrialization era: monetary developments, the balance of payments and the gold standard. fournal of Economic History 33, 339-7I.

Bhagwati, J. and Ramaswammim, V. K. (I963). Domestic distortions, tariffs, and the theory of optimum subsidy. Fournal of Political Economy 71, 44-50.

BoRODKIN, L. I. (2006). O promyshlennom roste dorevoliutsionnoi Rossii. Ekonomicheskaia istoriia, Obozrenie 12, I84-200.

BORODKIN, L. I. and LEONARD, C. S. (2000). The rural urban wage gap in the industrialisation of Russia, I885-1913. Oxford University, Department of Economics Working Paper no. I4.

BoRODKIN, L. I. and VALETOV, T. I. (I999). Dinamika differentsiatsii v oplate truda rabochikh-tekstil'shchikov i metalistov v Rossii v period dorevoliutsionnoi industrializatsii. In Ekonomicheskaia istoriia. Ezhegodnik. Moscow: ROSSPEN, pp. III-5I.

BORODKIN, L. I. and VALETOV, T. I. (200I). Mikroanaliz dannykh o kvalifikatsii i dinamike zarabotnoi platy rabochikh-tekstil'shchikov tovarishchestva manufaktur N. N. Konshina (konets XIX-nachalo XX v.). In Ekonomicheskaia istoriia. Ezhegodnik. Moscow: ROSSPEN, pp. 35I-88.

BOVYKIN, V. I. and LAVERYCHEV, A. (I984). Formirovanie finansovogo kapitala v Rossii: konets XIX v.-I908 g. Moscow: Nauka. 
BovYKIN, V. I. et al. (I989). Monopolisticheskii kapitalizm v Rossii: sbornik nauchnykh trudov. Moscow: Akademiia nauk SSSR In-t istorii SSSR.

BOYER, G. R. and HATTON, T. J. (1994). Regional labour market integration in England and Wales, I850-1913. In G. Grantham and M. MacKinnon (eds.), Labour Market Evolution: The Economic History of Market Integration, Wage Flexibility and the Employment Relation. London and New York: Routledge, pp. 84-IO6.

Boyer, G. R. and Hatton, T. J. (I997). Migration and labour market integration in late nineteenth-century England and Wales. Economic History Review 50 (4), 697-734.

BRADley, J. (1985). Muzhik and Muscovite: Urbanization in Late Imperial Russia. Berkeley, CA: University of California Press.

Cheetham, R. J., A. C. Kelley and J. G. Williamson (I974). Demand, structural change, and the process of economic growth. In P. A. David and M. W. Reder (eds.), Nations and Households in Economic Growth: Essays in Honor of Moses Abramovitz. New York: Academic Press, pp. 239-63.

CRISP, O. (1976). Studies in the Russian Economy before I9I4. London: Macmillan.

DANILOV, V. P. (1976). Ob istoricheskikh sud'bakh krest'ianskoi obshchiny v Rossii. Ezhegodnik po agrarnoi istorii, vyp. VI, Problemy istorii russkoi obshchiny, pp. IO3-6.

DE VRIES, J. (1994). How did pre-industrial labour markets function? In G. Grantham and M. MacKinnon (eds.), Labour Market Evolution: The Economic History of Market Integration, Wage Flexibility and the Employment Relation. London and New York: Routledge, pp. 39-63.

Dolado, J. J., JENkinson, T. J. and Sosvilla-Rivero, S. (I990). Co-integration and unit roots: a survey. Fournal of Economic Surveys 4 (3), 249-73.

Elliot, G., Rothenberg, T. J. and Stock, J. H. (I996). Efficient tests for an autoregressive unit root. Econometrica 64, 8I3-36.

FEI, J. C. H. and RANIS, G. (1964). Development of the Labour Surplus Economy: theory and policy. Homewood, IL: R. D. Irwin.

FEI, J. C. H. and RANIS, G. (1997). Growth and Development from an Evolutionary Perspective. Oxford: Blackwell.

GERSCHENKRON, A. (I952). An economic history of Russia. Fournal of Economic History I2, I46-59.

GersChENKRON, A. (I962a). Economic Backwardness in Historical Perspective. Cambridge, MA: Harvard University Press,

GERSCHENKRON, A. (1962b). Russia: patterns and problems of economic development, I86I-I958. In Economic Backwardness in Historical Perspective: A Book of Essays. Cambridge, MA: Harvard University Press, pp. II9-5I.

Goldsmith, R. (I96I). The economic growth of tsarist Russia. Economic Development and Cultural Change 9, 44I-75.

Goodwin, B. K. and GRENNES, T. J. (1998). Tsarist Russia and the world wheat market. Explorations in Economic History 35, 405-30.

GRANGER, C. W. J. (I986). Developments in the study of co-integrated economic variables. Oxford Bulletin of Economics and Statistics, 213-228.

GRANTHAM, G. (1989). Agricultural supply during the Industrial Revolution: French evidence and European implications. Fournal of Economic History 49, $43-72$. 
Grantham, G. and MACKInNON, M. (eds.) (1994). Labour Market Evolution: The Economic History of Market Integration, Wage Flexibility, and the Employment Relation. London and New York: Routledge.

GREGORY, P. R. (I980). Grain marketings and peasant consumption, Russia, I885-I9I3. Explorations in Economic History 17, I35-64.

GREGORY, P. R. (I982). Russian National Income, I885-I9I3. Cambridge: Cambridge University Press.

Gregory, P. R. (1994). Before Command: An Economic History of Russia from Emancipation to the First Five-Year Plan. Princeton, NJ: Princeton University Press.

Gregory, P. and SAILORS, J. W. (1976). Russian monetary policy and industrialization, I86I-I9I3. Fournal of Economic History 36, 836-5I.

Hamburg, G. M. (1978). The crisis in Russian agriculture: a comment. Slavic Review 37, 480-I.

HARRISON, M. (I990). The peasantry and industrialization. In R. W. Davies (ed.), From Tsarism to the New Economic Policy. Ithaca, NY: Cornell University Press, pp. IO4-24.

HATTON, T. J. and Williamson, J. G. (I99ia). Integrated and segmented labor markets: thinking in two sectors. Fournal of Economic History 5I, 4I3-25.

Hatton, T. J. and Williamson, J. G. (I99Ib). Wage gaps between farm and city: Michigan in the 1890s. Explorations in Economic History 28, 38I-408.

HatTon, T. J. and Williamson, J. G. (I992). What explains wage gaps between farm and city? Exploring the Todaro model with American evidence, I890-I94I. Economic Development and Cultural Change 40, 267-94.

HuNT, E. H. (1986). Industrialization and regional inequality: wages in Britain, I760-I9I4. Fournal of Economic History 46, 935-66.

HunT, E. H. and PAM, S. J. (I997). Prices and structural response in English agriculture, I873-I896. Economic History Review 50, 477-505.

JOHANSEN, S. (1988). Statistical analysis of cointegrating vectors. Fournal of Economic Dynamics and Control 12, pp. 23I-54.

JOHANSEN, S. (I99I). Estimation and hypothesis testing of cointegration vectors in Gaussian vector autoregressive models. Econometrica 59, I55 I-80.

JoHANSEN, S. (1995). Likelihood-based Inference in Cointegrated Vector Autoregressive Models. Oxford: Oxford University Press.

JOHANSEN, S. and K. JUSELIUS (I990). Maximum likelihood estimation and inference on cointegration with applications to the demand for money. Oxford Bulletin of Economics and Statistics 52, pp. I69-2 IO.

JONES, D. W. (1975). Migration and urban unemployment in dualistic economic development. Chicago: Department of Geography, University of Chicago, Research Paper no. I65.

KAFENGaUZ, L. B. and VARZAR, V. E. (1929). Svod statisticheskikh dannykh o fabrichno-zavodskoi promyshlennosti s I887 po I926 goda [Microform]. Moscow: Gos. Izd-vo.

KAHAN, A. (1967). Government policies and the industrialization of Russia. fournal of Economic History 27, 460-77.

KIRYANOV, IU. I. (I987). Perekhod $k$ massovoi politicheskoi bor'be: rabochii klass nakanune pervoi rossiiskoi revoliutsii. Moscow: Nauka. 
KIRYANOV, IU. I and VOLIN, M. S. (I989). Robochii klass Rossii ot zarozhdeniia do nachala $X X v$. Moscow: Nauka.

Kotwal, A. and RAMSwami, B. (I998). Economic reforms in agriculture and rural growth. Fournal of Policy Reform 2, 369-402.

Koval'CHENKO, I. D. and MILOV, L. V. (I974). Vserossiiskii agrarnyi rynok, XVIII-nachalo XX v. Moscow: Nauka.

Koval'CHenko, I. D., Selunskaia, N. B. and Litvakov, B. M. (I982). Sotsial'no-ekonomicheskii stroi pomeshchichego khoziaistva evropeiskoi Rossii v epokhu kapitalizma: istochniki i metody izucheniia. Moscow: Nauka.

KraVCHENKO, A. I. (2000). Antologiia sotsial'no-ekonomicheskoi mysli v Rossii: dorevoliutstionnyi period. St Petersburg: Russkii Khristianskii Gumanitarnyi Institut.

Kwiatkowski, D., Phillips, P. C. B. et al. (I992). Testing the null hypothesis of stationarity against the alternative of a unit root: how sure are we that economic time series have a unit root? fournal of Econometrics 54, I59-78.

LEONARD, C. S. (I990). The Russian peasant commune under serfdom. In R. Bartlett (ed.), Land Commune and Peasant Community in Russia: Communal Forms in Imperial and Early Soviet Society. New York: St Martin's Press, pp. I $2 \mathrm{I}-42$.

LEONARD, C. S. (forthcoming). Agrarian Reform in Russia, I86I-2007. Cambridge: Cambridge University Press.

LEWIN, M. (I990). The obshchina and the village. In R. Bartlett (ed.), Land Commune and Peasant Community in Russia: Communal Forms in Imperial and Early Soviet Society. London: Macmillan, pp. 20-44.

LEWIS, W. A. (1954). Economic development with unlimited supplies of labour. Manchester School of Economics and Social Studies 20, 139-92.

MARGO, R. A. (2002). The North-South wage gap, before and after the Civil War. NBER Working Paper 8778.

Mironov, B. N. (I99I). Istoriia $v$ tsifrakh. Leningrad: Nauka.

Mironov, B. N. (2006). From paradigm to myth: a response to B. V. Anan'ich. In Ekonomicheskaia istoriia ezhegodnik. Moscow: ROSSPEN, pp. 54I-6.

NG, S. and PERron, P. (200I). Lag length selection and the construction of unit root test with good size and power. Econometrica 69, I519-54.

Nifontov, A. S. (I974). Zernovoi priozvodstvo Rossii vo vtoroi polovine XIX veka. Moscow: Nauka.

Pazhitnov, K. A. (1924). Polozhenie rabochego klassa v Rossii. Leningrad: Nauka, V. 3.

PeSARAN, M. H. and SHIN, Y. (I995a). Long run structural modelling. DAE Working Paper, Department of Applied Economics, University of Cambridge.

PESARAN, M. H. and SHIN, Y. (I995b). An autoregressive distributed lag modelling approach to cointegration analysis. DAE Working Paper 95I4, Department of Applied Economics, University of Cambridge.

Pesaran, M. H., SHIN, Y. and SMITH, R. J. (1996). Testing for the existence of a long-run relationship. DAE Working Paper 9622, Department of Applied Economics, University of Cambridge.

Pesaran, M. H., SHIN, Y. and SMITH, R. J. (200I). Bounds testing approaches to the analysis of long-run relationship. Fournal of Applied Econometrics 16, 289-326. 
Phillips, P. C. B. and PERron, P. (I988). Testing for a unit root in time series regression. Biometrika 75, 335-46.

RADTSIG, A. (I896). Vliane zheleznykh dorog na sel'skoe khoziastvo, promyshlennost' $i$ torgovliu. St Petersburg.

RASHIN, A. G. (I940). Formirovanie promyshlennogo proletariata v Rossii: statistiko-ekonomicheskie ocherki. Moscow: Sotsial'no-Ekonomicheskoi Literaturoi.

RASHIN, A. G. (I956). Naselenie Rossii za Ioo let (I8II-I9I3), Statisticheskii ocherki. Moscow: Gosudarstvennoe Statisticheskoe Izdatel'stvo.

RosenBlOOM, J. L. (1990). One market or many? Labour market integration in the late nineteenth century United States. Fournal of Economic History 50, 85-106.

Rosenbloom, J. L. (I996). Was there a national labor market at the end of the nineteenth century? New evidence on earnings in manufacturing. Fournal of Economic History 56, 626-56.

RossIA. Materialy vysochaishe uchrezhdenoi I6 noiabria I9oI g. komissii po issledovaniiu voprosa o dvizhenii s I86I po I9oI g. blagosostianiia sel'skogo naseleniia srednezemledel'cheskikh gubernii (1903). St Petersburg, ch. I, tab. I9.

RossIA. Ministerstvo zemledeliia. Otdel sel'skoi ekonomiki i selkhokhoziastvennoi statistiki (I88I-I9I9)....god v sel'skokhoziastvennom otnoshenii po otvetam, poluchennym ot khoziaev, St Petersburg (cited as MGZU SKh).

ROTHENBERG, W. B. (I988). The emergence of farm labour markets and the transformation of the rural economy: Massachusetts, I750-I855. Fournal of Economic History 48, 537-66.

RYKaCHEV, A. (I9II). Tseny na khleb i na trud v S.-Petersburge za 58 let. Viestnik finansov $3 \mathbf{r}$.

RYNDZIUNSKII, P. G. (1983). Krestiane $i$ gorod v kapitalisticheskoi Rossii vtoroi poloviny XIX veka (Vzaimootnoshenie goroda $i$ derevni $v$ sotsial'no-ekonomicheskom stroem Rossii). Moscow: Nauka.

Schultz, T. W. (1945). Agriculture in an Unstable Economy. New York: McGraw-Hill Book Co.

Simms, J. Y. (1977). The crisis in Russian agriculture at the end of the nineteenth century: a different view. Slavic Review 36, 377-98.

Simonova, M. S. (I97I). Problema 'oskudeniia' Tsentra i ee rol' v formirovanii agrarnoi politiki samoderzhaviia v 90-kh godakh XIX-nachale XX v. Problemy sotsial'no-ekonomicheskoi istorii Rossii, sbornik statei. Moscow: Nauka.

STOPANI, A. M. (I9I6). Neftepromyshlennyi rabochii i ego biudget. Baku.

STRUMILIN, S. G. (1960). Ocherki ekonomicheskoi istorii Rossii. Moscow: Nauka.

STRUMILIN, S. G. (I963). Statistika $i$ ekonomika, Izbrannye proizvedeniia v piati tomakh. Moscow: Nauka, v. I.

STRUMILIN, S. G. (I964). Problemy ekonomiki truda, Izbrannye proizvedeniia v piati tomakh. Moscow: Nauka, v. 3.

STRUMILIN, S. G. (I967). Istoriia chernoi metallurgii $v$ SSSR. Moscow: Nauka.

Svod otchetov fabrichnykh inspektorov za I904 g. (I905). St Petersburg.

Tekhnicheskoe opisanie Kolomenskogo mashinostroitel'nogo zavoda, I863-1903 gg. (I903). Kolomna.

TODARO, M. P. (1969). A model of labour migration and urban unemployment in less developed countries. American Economic Review 59, I38-48. 
Todaro, M. P. (1976). Internal Migration in Developing Countries: A Review of Theory, Evidence, Methodology and Research Priorities. Geneva: International Labour Office of the UN.

TUgan-BARANOVSKy, M. I. (1922). Russkaia fabrika. Moscow.

UNGER, K. (2005). Regional economic development and Mexican out-migration. NBER Working Paper Wi 432.

VAINSHTEIN, A. L. (I960). Narodnoe bogatstvo i narodnokhoziastvennoe nakopleniepredrevoliutsionnoi Rossii. Moscow: Gosstatizdat.

VAINSHTEIN, A. L. (1967). Statistika narodnogo bogatstva. Moscow: Gosstatizdat.

WheAtcroft, S. G. (1990). Agriculture. In R. W. Davies (ed.), From Tsarism to the New Economic Policy: Continuity and Change in the Economy of the USSR. Ithaca, NY: Cornell University Press, pp. 79-103.

WilliamsON, J. G. (1987). Did English factor markets fail during the Industrial Revolution? Oxford Economic Papers, NS 39, 64I-78.

Williamson, J. G. (1990). Coping with City Growth During the British Industrial Revolution. Cambridge: Cambridge University Press.

WiLliamson, J. G. (1994). Leaving the farm to go to the city: did they leave quickly enough? In J. A. James, M. Hartwell and M. Thomas (eds.), Capitalism in Context: Essays on Economic Development and Cultural Change in Honor of R. M. Hartwell. Chicago: University of Chicago Press, pp. I59-82. 
Appendix I. Nominal daily agricultural and urban (construction) wages, St Petersburg and rural environs, index, I884-I910

\begin{tabular}{lcc}
\hline \hline Year & $\begin{array}{l}\text { Agricultural daily wages } \\
\text { (seasonal average) }\end{array}$ & $\begin{array}{l}\text { Urban daily wages, } \\
\text { construction workers }\end{array}$ \\
\hline I884 & 79 & 73 \\
I885 & 65 & 75 \\
I886 & 70 & 65 \\
I887 & 74 & 65 \\
I888 & 72 & 78 \\
I889 & 74 & 82 \\
I890 & 74 & 82 \\
I891 & 72 & 84 \\
I892 & 67 & 85 \\
I893 & 72 & 87 \\
I894 & 74 & 85 \\
I895 & 76 & 85 \\
I896 & 72 & 85 \\
I897 & 79 & 83 \\
I898 & 80 & 94 \\
I899 & 84 & 98 \\
I900 & 84 & 83 \\
I90I & 86 & 94 \\
I902 & 84 & 99 \\
I903 & 89 & 97 \\
I904 & 76 & 96 \\
I905 & 89 & IOI \\
I906 & 89 & IO2 \\
I907 & 93 & II 4 \\
I908 & 98 & I IO \\
I909 & 98 & I IO \\
I910 & 100 & IOO \\
\hline \hline
\end{tabular}

Source: Rykachev (I9I I); Rossia, Ministerstvo zemledeliia, Otdel sel'skoi ekonomiki i selkhokhoziastvennoi statistiki (I88I-I9I9). ...god v sel'skokhoziastvennom otnoshenii po otvetam, poluchennym ot khoziaev, St Petersburg. 